\title{
Competing for Space: Factors That Lead to Sponge Overgrowth When Interacting with Octocoral
}

\author{
Elizabeth L. Mclean",2, Klaus Rützler ${ }^{3}$, Penelope S. Pooler ${ }^{4}$ \\ ${ }^{1}$ Department of Natural Resource Sciences, University of Rhode Island, Kingston, RI, USA \\ ${ }^{2}$ Graduate Program in Evolution, Ecology and Behavior, University at Buffalo, Buffalo, NY, USA \\ ${ }^{3}$ Department of Invertebrate Zoology, Smithsonian Institution, Washington DC, USA \\ ${ }^{4}$ Department of Public Health and Preventive Medicine, Upstate Medical University-SUNY, Syracuse, NY, USA \\ Email: elmclean@my.uri.edu
}

Received 19 November 2014; revised 8 December 2014; accepted 18 December 2014

Copyright (C) 2015 by authors and Scientific Research Publishing Inc.

This work is licensed under the Creative Commons Attribution International License (CC BY).

http://creativecommons.org/licenses/by/4.0/

(c) (i) Open Access

\section{Abstract}

The overgrowth of octocorals by sponges is generally disadvantageous for the octocorals. When the growth of octocoral populations increases the reefs' structural complexity, more substrate space becomes available for epibionts to grow. One of these epibionts is the sponge Desmapsamma anchorata, known to grow exponentially faster than other sponges, and for its ability to overwhelm the substrate over which it grows. Our objective in this study is to determine if the overgrowth of branching octocorals by varying sponges is defined only by species-specific interactions, or if some physical attributes make this octocoral more susceptible to being overgrown than others. To determine this, on a reef south of Carrie Bow Cay, Belize, we monitored the attachment of various demosponges to branching octocorals in a series of experiments to assess the response effect of the interactions and properties leading to attachment and subsequent sponge overgrowth on branching octocorals. Substrate effects, species-specific reactions, and time of exposure were considered. Additionally, following successful-attachment, preliminary growth rates of two sponge species epizoic on two octocoral species were monitored. Differences in the observed interaction between species and treatments were analyzed with a multinomial response model to isolate a species-specific effect from other interacting effects of the properties tested. Results indicate that time of exposure of a sponge in direct contact with the octocoral fragment significantly affects the outcome of the interaction; secondly, physical properties and species-specific interactions also influence the attachment. Following the successful attachment to an octocoral, the growth of the sponge varies as a function of the sponge's differential growth rate and the substrate species over which it grows. In the context of species successions, understanding interactions between coralreef organisms is important as these interactions explain species composition and diversity, and provide a basis for the prediction of future changes in complex reef communities. 


\section{Keywords}

\section{Porifera, Gorgonacea, Interactions, Attachment, Overgrowth}

\section{Introduction}

This study measures attachment of sponges on octocorals and tests the attachment of common demosponge species, such as Desmapsamma anchorata (Carter) and Iotrochota birotulata (Higgins), when overgrowing two common branching octocorals, Antillogorgia americana (Gmelin) and Eunicea flexuosa (Lamouroux), and testing other less common sponge-octocoral pairings to investigate if species-specific effects alone explain the sponge's attachment, or if other physical properties of the organisms, and the time of exposure, influence the attachment that precedes the sponge overgrowth. The process to be considered in the background of this study is the role that successional settlement and subsequent interactions play in the shaping of a coral reef complex. Of the main sponge species tested, Desmapsamma anchorata stands out as a sponge species that can grow many times faster than other sponge species, and can overgrow many different organisms [1]-[4].

Many species of sponges commonly interact with octocorals [3]-[5]. Earlier reports on sponge-octocoral interactions include studies of the frequency and distribution of interactions [2] [4]-[8] and mechanisms of interaction [3]. Observation on reef population studies (2002-2006, NOAA-CRES ${ }^{1}$ program) suggest that the frequency of occurrence of specific sponge-octocoral interactions on a reef is random, a simple function of species' abundances on a given reef but that the nature of the interaction is not [5]. Changes in a reef can occur in a matter of decades, as Yoshioka and Yoshioka (1989) determined while monitoring octocoral populations on two reefs in southwestern Puerto Rico following the die-off of the sea urchin Diadema antillarum (Philippi), an important grazer [9]. They noted that as octocoral populations increased, more individuals of $D$. anchorata were growing on the monitored octocorals. In their assessment they found that $6.7 \%-14 \%$ of the octocoral colonies had broken branches and many of these branches had thin layers of $D$. anchorata and in some cases also Amphimedon viridis (Duchassaing \& Michelotti) covering the bare axial skeleton [10]. For the sites they studied and other reefs surveyed during 2001-2006, D. anchorata was found to be the predominant demosponge associated with octocorals at both of those sites, and on other reefs in this region [3]. The second sponge here considered, Iotrochota birotulata, too is commonly found to overgrow octocorals [4] and together with $D$. anchorata, has been observed growing abundantly on shipwrecks [11].

Sponges are known to be proficient epibionts [12] that maximize acquisition of substrate space by overgrowing other organisms. Environmental factors and ecological interactions between organisms that compete and generate space influence and shape the complex physical structure of reefs [13]. While corals are often the focus of studies on reefs, sponges too are common members of reefs, especially at Caribbean sites, where they interact with a wide variety of taxa, both producing and modifying the reef [14] [15]. Sponge species create habitat for a variety of taxa [16] [17] and engage in mutualisms with them, generating complex associations [12] [18] [19]. They also compete for space with corals and other sessile invertebrates [4] [20]-[27] and may end up as "structural parasites" that is, overgrowing other species without killing them, including octocorals [1]-[3] [16].

Interaction response effects observed between benthic organisms are often explained as functions of their allelopathic properties, chemicals produced by sponges or their microbial endosymbionts [28]-[30]. The production of these allelochemicals is a common defense mechanism of both branching [19] [31] [32] and encrusting sponges [20] [30] [33]. These known defense mechanisms explain overgrowth, and possible killing between competing benthic (sessile) species, enabling the sponges to obtain new substrate space [34] [35] and influencing the occurrence of associated species and their interactions.

Sponge attachment is an important process because it is the first step enabling the animals to foul and outcompete other invertebrates. Attachment, here defined as the adherence of an organism's tissue to that of another, is not always mandatory in overgrowth situations; some sessile organisms spread and grow loosely over other sessile encrusting organism [26] without adhering histologically. However, attachment is generally the outcome when sponges overgrow branching octocorals [3] [5]. Overgrowth, as defined by Stebbing (1973), is the extension of the edge of a sessile organism over the edge of another; from this initial extension, it is assumed that the

${ }^{1}$ Coral Reef and Ecosystem Studies (CRES). 
dominant organism will be able to overgrow, kill and outcompete the other [36]. Conversely, there are instances where the shrinkage of overgrowth after initial spreading has been described [22] [37] [38].

\section{Materials and Methods}

\subsection{Study Site}

Experiments were carried out in June 2009 and January-February 2010 on a patch reef $2.5 \mathrm{~km}$ south of Carrie Bow Cay, Belize $\left(16^{\circ} 48.173^{\prime} \mathrm{N}, 88^{\circ} 4.928^{\prime} \mathrm{W}\right)$ at $8.5 \mathrm{~m}$ deep (Figure 1). The site was well suited for the study because of high sponge abundance, a diverse octocoral population, and signs of common sponge-octocoral interactions.

\subsection{Study Species}

The branching sponges and octocorals used in the experiments are representative of species common to many Caribbean reefs. All sponges belong to the class Demospongiae: Desmapsamma anchorata (Poecilosclerida, Desmacididae) and Iotrochota birotulata (Poecilosclerida, Iotrochotidae) commonly overgrow octocorals; $\mathrm{Ni}$ phates erecta (Duchassaing \& Michelotti) (Haplosclerida, Niphatidae) and Ptilocaulis walpersi (Duchassaing \& Michelotti) (Halichondrida, Axinellidae) are rarely found epizoic on octocorals. N. erecta has been observed growing on the sea fan Gorgonia ventalina (Linnaeus) [5] but never on branching octocoral species.

As morphology influences the nature of species interactions [26], our four selected species span a range of shapes and distributions: Desmapsamma anchorata (Figure 2(B) and Figure 2(C)) is encrusting to arborescent, widespread, found from near-shore to oceanic habitats and from calm deep water to exposed shallow reef habitats [21] [39] [40]. D. anchorata grows fast, is easily torn, exudes slippery mucus upon tearing [40] and produces a variety of secondary metabolites and anti-predatory toxins [41] [42]. Its growth is described as weedy, growing substantially faster than other branching sponges [1] [43]. Iotrochota birotulata is ramose, has a tough, compressible consistency and a spiky surface; it can be covered with symbiotic zooanthids [44] [45] (Figure 2(A) and Figure 2(D)), which are reported to repel predators [46] and increase the sponge's chance of survival [47].

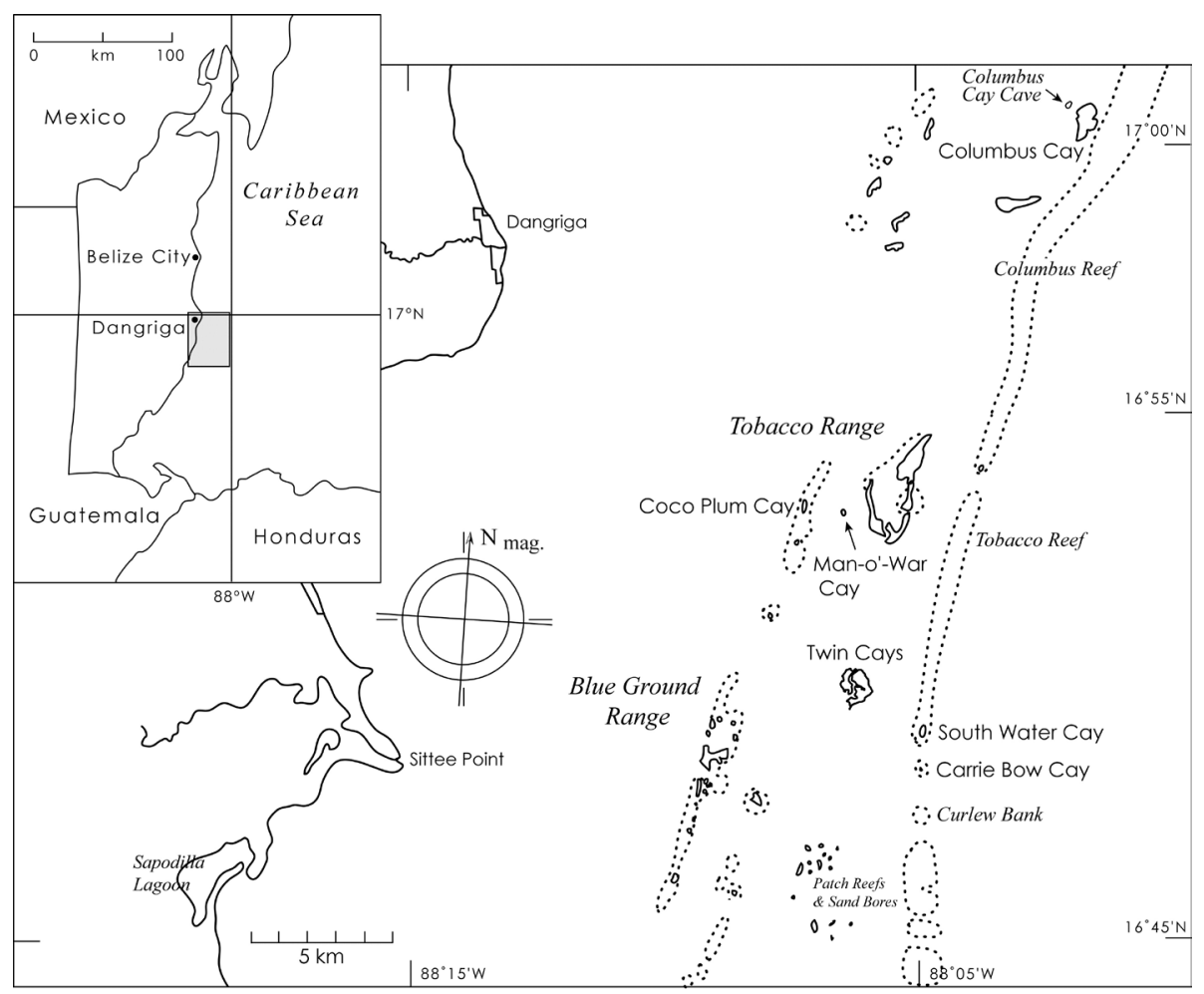

Figure 1. Map of cays on the east coast of Belize. The study site was located in a reef patch 2.5 km South of Carrie Bow Cay. (Map prepared by Molly Ryan 2014) 


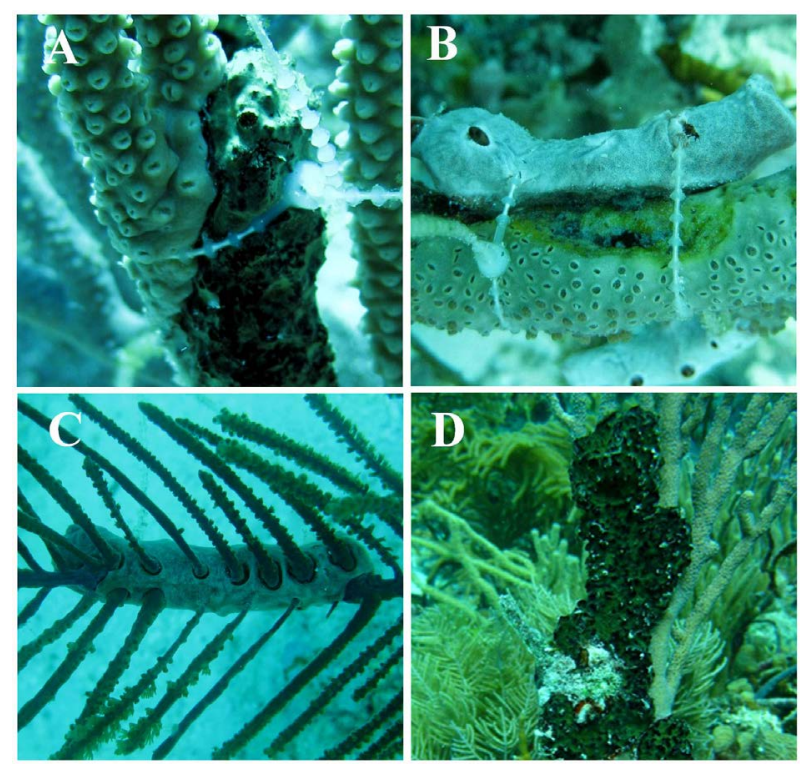

Figure 2. Representative sponge-octocoral interactions tested: Iotrochota birotulata on Eunicea mammosa (A); polyps in contact with the sponge appear swollen. Desmapsamma anchorata on Plexaurella nutans, $P$. nutans' tissue died/receded at the margin of contact leaving a layer of sclerites (B); Desmapsamma anchorataon Antillogorgia americana showing attachment on bare axis within 2 days (C); I. birotulata attached to Plexaura kuna (D).

Niphates erecta and Ptilocaulis walpersi too are branching sponges that are widely distributed in the Caribbean and found on reefs and other hard bottoms [48] [49]. Their growth forms and colors are variable. N. erecta can be erect ramose, massive, or encrusting. Its surface is conulose, its consistency, compressible and tough and is frequently found covered by the zoanthid Parazoanthus parasiticus [40] [50] [51]. N. erecta differs from P. walpersi in that it is considered chemically undefended or poorly defended, although it has been reported to encroach on and overgrow the coral Madracis mirabilis (Lyman) [34]; in contrast to other chemically undefended or poorly defended sponges, $N$. erecta grows slowly [11]. $P$. walpersi is chemically defended, but deters generalist fishes to a lesser degree than other chemically defended sponges [11]. $P$. walpersi morphology is characterized by an erect, finger-shaped body with dichotomous branches; it can grow also encrusting or fan-shaped, its surface ornamented by spiny, or round and blunt, or spatula-shaped projections. Although not frequently found associated with octocorals, $P$. walpersi is found to overgrow stony corals and is a considered a strong space competitor [52].

The octocorals (Gorgonacea) chosen for the experiments have different, distinct morphologies. Most branching species in the Caribbean have a semi-rigid scleroproteinaceous axis [53] that, if exposed after tissue death, becomes a substrate over which sponges and other organisms may grow. Antillogorgia americana (Gorgoniidae) colonies are tall with long regular plume-like branches; they are slimy to the touch and can produce copious amounts of mucus containing predator-deterrent compounds [54]. Eunicea flexuosa (Plexauridae) colonies range from candelabrum-like to bushy, with a surface that is smooth or bumpy with many calices [54]. Plexaurella nutans (Duchassaing \& Michelotti) (Plexauridae) similarly has candelabrum-like colonies, with a branch surface that has the texture of fine sandpaper; it has not been observed with sponge overgrowth [54].

\subsection{Methods}

\subsubsection{Experimental Design}

Different from studies that quantify and describe allelochemicals in benthic interactions, and the complex makeup of these defense mechanisms, we take an experimental approach to assess factors that determine the ability of a sponge to attach to an octocoral substrate. The described interaction effects consist of visible changes on the octocoral tissue as a result of its direct contact with the sponge; effects are noted sequentially as: discoloration, tissue death, and attachment or non-attachment. The different factors tested are: 1) Physical effects sponges may have on octocorals during contact; 2) species-specific (mostly chemical) effects, or octocoral overgrowth deter- 
rence explained by species-specific defenses; and 3) octocoral reaction, whether the property of live or dead octocoral substrate influences its susceptibility to sponge attachment and overgrowth. Finally, after successful attachment 4) four different sponge-octocoral pairings are left to grow for 6 months and surveyed for sponge overgrowth along the octocoral axis. Octocoral overgrowth-deterrence is indicated by the absence of sponge attachment to the octocoral; the octocoral reactions are sequential effects observed on octocoral tissue. The analyses consisted of a multinomial response model that measured the effects of each factor tested on varying sponge-octocoral species pairings, and the effects of multiple combined factors.

Under natural conditions, sponges can establish themselves on octocorals either by spreading along the substratum, when drifting fragments become lodged at the base of the octocoral or in its branches, or when propagules settle on either an exposed colony axis or on living tissue. The experiments in this study were based on mimicking propagation via fragments.

For all experiments, sponges were collected from neighboring patch reefs and $5 \mathrm{~cm}$ long fragments cut with a stainless steel scissors. The fragments were allowed to heal by enclosing them in a mesh bag fixed above the substratum and exposed to flowing seawater at the study site. After the cut edges of the fragments healed, fragments were connected to the branches of standing, live octocoral colonies using small cable ties (Figure 2(A) and Figure 2(B)). Sponge fragments were placed on the octocorals in positions well above the reef substratum. Each treatment consists of 12 replicates. This assured optimal sponge growth [55] [56] and incorporates the enhanced growth that can occur in sponges that are located higher in the water column [8] [57] and experience exposure to higher water flow and thus increased in nutrient availability [58].

Responses of the sponge and octocoral were monitored every other day. The experiments and the multinomial analyses were designed to differentiate between physical effects from direct contact of a sponge to an octocoral, substrate effects (reaction by the gorgonian), and the interactive effects of specific species pairings, as well as the combined effects of multiple factors.

\subsubsection{Experiments}

\section{1) Physical effects sponges may have on octocorals during contact}

Octocorals interacting with sponges can be adversely affected by the direct physical action of smothering the tissue [3] [5] or through allelopathy [30]. The first experiment was designed to determine if the effects of an overgrowing sponge, observed on the octocoral tissue, are simply a function of the physical effects of overtopping and being in contact with the octocoral regardless of the physical property of the sponge. By physical property of the sponge we mean the tested fragments that are live, dead and an artificial tissue mimic, explained below. When a sponge fragment overgrows octocoral tissue, it does not necessarily attach to the tissue, but the interaction can cause tissue death or increase the octocoral's vulnerability to other fouling organisms, such as the fire coral Millepora alcicornis (Linnaeus) [6] or cyanobacteria [59]. The effects were measured for pairings consisting of all live octocoral axis, using inert and live fragments of the sponges Desmapsamma anchorata and Iotrochota birotulata; additional pairings used a tissue mimic, for control (Table 1). The live sponge fragments were prepared as described above. Dead sponge fragments were used to determine if just the physical structure of the sponge was sufficient to elicit an effect on the octocoral; these were prepared by rinsing live sponge fragments in ethanol, drying them in the sun, and then soaking them in sea water prior to their use. The tissue mimic, pieces of fiber skeleton of a commercial sponge, provided a control to determine whether the effects of dead sponge were species specific; it measured effects of other possible inert objects floating onto the gorgonian. Each of the three sponge tissue types were attached with cable ties to 12 branches of Antillogorgia americana colonies, 20 - $25 \mathrm{~cm}$ above their substrate [8]. That procedure was repeated for each of the two sponge species, including a replicate set of the tissue mimics tested on two different octocoral species, for a total of 12 replicates. Response of the octocoral generally followed a sequence from no visual effect, to discoloration, to tissue death (visible breakdown of the tissue). Attachment, adherence of the sponge to the octocoral axis, was also a possible outcome in trials using living sponge fragments. In some cases the sponge fragment would fall from the octocoral, usually due to wave action or the disintegration of the fragments. The time course of those generally-sequential responses was recorded, and the percentage of trials at each state determined for each day. If the loss of the overgrowing sponge was early in the experiment, the octocoral tissue often recovered slowly. Tissue death commonly followed a pattern of increasing discoloration and darkening of the tissue followed by necrosis.

2) Octocoral overgrowth-deterrence explained by species-specific pairings

Similar to experiment one, sponge-octocoral pairings were attached and monitored to study species-specific 
Table 1. Species pairings for testing attachment and growth success of epizoic sponges on octocorals.

\begin{tabular}{|c|c|c|c|}
\hline \multicolumn{4}{|c|}{ I. Physical effects on the octocoral } \\
\hline Sponge species & Attribute & Octocoral species & Attributes \\
\hline Desmapsamma anchorata & Live, commonly epizoic & Antillogorgia americana & Live, commonly overgrown \\
\hline Iotrochota birotulata & Live, commonly epizoic & A. americana & Live, commonly overgrown \\
\hline D. anchorata & Dead & A. americana & Live, commonly overgrown \\
\hline I. birotulata & Dead & A. americana & Live, commonly overgrown \\
\hline Tissue mimic & Dead & A. americana & Live, commonly overgrown \\
\hline \multicolumn{4}{|c|}{ II. Octocoral overgrowth deterrence explained by species-specific combinations (all live) } \\
\hline D. anchorata & Live, commonly epizoic & A. americana & Commonly overgrown \\
\hline D. anchorata & Live, commonly epizoic & Eunicea flexuosa & Commonly overgrown \\
\hline I. birotulata & Live, commonly epizoic & A. americana & Commonly overgrown \\
\hline I. birotulata & Commonly epizoic & E. flexuosa & Commonly overgrown \\
\hline Niphates erecta & Rarely epizoic & A. americana & Commonly overgrown \\
\hline N. erecta & Rarely epizoic & E. flexuosa & Commonly overgrown \\
\hline Ptilocaulis walpersi & Rarely epizoic & A. americana & Commonly overgrown \\
\hline P. walpersi & Rarely epizoic & E. flexuosa & Commonly overgrown \\
\hline D. anchorata & Commonly epizoic & Plexaurella nutans & Rarely overgrown \\
\hline \multicolumn{4}{|c|}{ III. Octocoral reaction } \\
\hline D. anchorata & Live, commonly epizoic & A. americana & Live, commonly overgrown \\
\hline I. birotulata & Live, commonly epizoic & E. flexuosa & Live, commonly overgrown \\
\hline D. anchorata & Live, commonly epizoic & P. nutans & Live, rarely overgrown \\
\hline D. anchorata & Live, commonly epizoic & A. americana & Dead, commonly overgrown \\
\hline I. birotulata & Live, commonly epizoic & E. flexuosa & Dead, commonly overgrown \\
\hline D. anchorata & Live, commonly epizoic & P. nutans & Dead, rarely overgrown \\
\hline
\end{tabular}

effects. By testing pairings that occur and pairings that do not occur on samples of both sponge and octocoral species that are known to be proficient epibionts, or rarely overgrown substrate (Table 1), we seek to determine what attributes explains for the occurrence of a sponge-octocoral interactions when common epizoic sponges are not observed to overgrow a given octocoral species. Occurrence and non-occurrence denomination were based on years of observations; for instance in a recent survey were 188 sponge-octocoral interactions were recorded, D. anchorata overgrew Antillogorgia americana 35\%, Eunicea flexuosa $6 \%$ and interacted with Plexaurella nutans 1.5\%, showing discoloration, and no signs of attachment (Mclean unpublished, 2010). Deterrence effect is assumed absent when the octocoral tissue has been removed and the sponge is in direct contact with the octocorals axis.

The different pairings tested account for 1) sponge-octocoral pairings that commonly occur on the reef, such as epizoic Desmapsamma anchorata and Iotrochota birotulata which attach-to and grow on Antillogorgia americana and Eunicea flexuosa; 2) sponge-octocoral pairings with sponges that are natural and common epizoans on other organism, including octocorals, $D$. anchorata and $I$. birotulata, but that have not been observed to overgrow the octocoral Plexaurella nutans. And lastly, we tested 3) pairings of sponges that are rarely epizoics on octocorals were tested: Ptilocaulis walpersi and Niphates erecta, with the octocoral A. americana, which is commonly overgrown by the epizoic sponge species. We hypothesized that the commonly epizoic cases of sponge overgrowth on the reef are those in which a sponge species is capable of either killing the octocoral 
tissue and then attaching to the axis, or attaching directly to the octocoral tissue and subsequently killing it or not. Furthermore, we were interested in determining if these abilities varied with available octocoral substrate species.

\section{3) Octocoral reaction-differences in octocoral susceptibility to overgrowth}

In the first experiment we described response effects observed on the octocoral explained by a mere physical interaction with a sponge fragment in direct contact with it, this third experiment examines the variability in the attachment response effect when the octocoral substrate is alive or dead, thereby testing its suitability for sponge attachment. For this purpose, half of the experiments were done on octocorals with live tissue removed, the other half with tissue intact. Approximately $7 \mathrm{~cm}$ length of live tissues was removed from standing live octocoral colonies using medical scissors and a scrubber to clean and completely expose the octocoral's semi-rigid axis. Sponge fragments, $5 \mathrm{~cm}$ long, were connected to these bare areas as well as to healthy tissue using small cable ties and were then monitored. Speed of attachment was measured in number of days. Once attachment was noted, the cable ties were removed and the sponges left attached to the octocoral by their own means. For this experiment, Demapsamma anchorata and Iotrochota birotulata were tested on Antillogorgia americana and Eunicea flexuosa on which they naturally occur. Additionally, D. anchorata was tested on live and bare Pleaxaurella nutans substrate, which it does not usually overgrow (Table 1 ).

We hypothesized that if sponge-octocoral associations are not strictly species-specific, sponge attachment occurs on both live and dead octocoral substrates, indifferent of the species. Alternatively, if there is a speciesspecific effect, some octocorals with live tissue can deter the sponges from attaching, whereas in absence of live tissue, sponges attach to the bare octocoral axis.

\section{4) Growth measurements of sponges attached to octocorals}

After conducting the initial experiments in July 2009, four sponge-octocoral pairings were labeled and mapped in our study site. These were left to grow for a period of 6 months and their growth measured a second time in January 2010. These experimental pairings numbered thirteen to fourteen replicates each consisting of sponge fragments already attached and growing $20-25 \mathrm{~cm}$ above the of the reef substrate, as explained above.

The species pairings for this experiment were the sponges Desmapsamma anchorata and Iotrochota birotulata on the octocorals Antillogorgia americana and Eunicea flexuosa. To measure their growth, the sponge fragments on the octocorals were photographed underwater using a Canon digital camera (2048 $\times 1536$ pixel resolution) using a grid reference $(2.54 \times 2.54 \mathrm{~cm})$ provided on a clip board (Figure 3$)$.

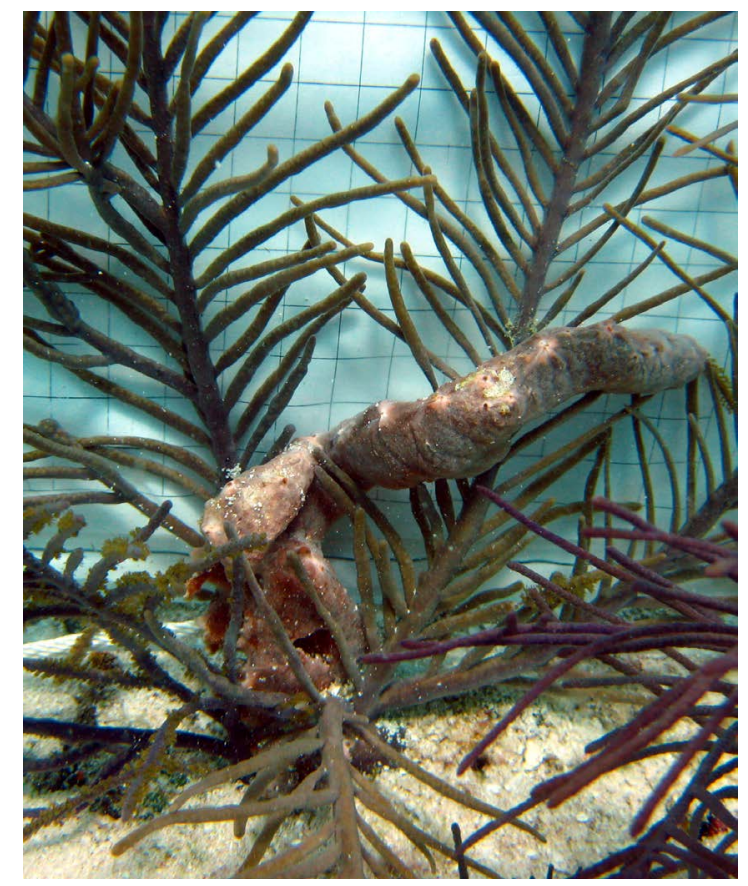

Figure 3. Naturally occurring example of growth of Desmapsamma anchorata on Antillogorgia americana. Gridlines set at $2.54 \mathrm{~cm}$ intervals. 
Growth measurements were analyzed using ImageJ software. The measurements consisted of sponge growth area $\left(\mathrm{cm}^{2}\right)$ and longitudinal growth $(\mathrm{cm})$ along the octocoral's axis. In July 2009, the initial length of the fragments was $5 \mathrm{~cm}$; they were re-measured after 6 month. We recognize that sponges grow tridimensionally, so this preliminary assessment is both on the growth area and the length of the sponge that extends on the octocoral axis, this being the core structural part of the octocoral that can compromise the colony if debilitated. The branching growth of the frail $D$. anchorata are often broken by currents [3] [60] enabling their continual recruitment and dispersal. The monitored sponge growth serves to compare the rapid epizoic sponge growth in contrast to slower host growth; branching octocorals roughly grow $1-2 \mathrm{~cm}$ a year length wise [10]. Results of the three experiments were analyzed using the GENMOD procedure of the SAS statistical software package (SAS Version 9.2). For each experiment, binomial or multinomial responses were used, depending on whether it was at a two level response (attached or not attached) or a multi-response level (more than two) (Table 1).

\section{Results}

\subsection{Physical Effects Sponges May Have on Octocorals during Contact}

Results are for 12 replicates per treatment, testing three different physical properties of the sponge (live, dead, tissue mimic) on the octocoral Antillogorgia americana. Initial observations, on the first 5 days, were consistent when testing the physical properties of the sponges, for all samples when different sponge fragments were in contact with the octocoral tissue responses observed ranged from discoloration to tissue death. Generally, the time of exposure, 1 - 8 days, significantly influenced the response on the octocoral $\left(F_{2,136}=22.82, P<0.0001\right)$, as well as the physical property of the sponge fragment in contact with the octocoral substrate $\left(\mathrm{F}_{2,136}=4.54, \mathrm{P}=\right.$ 0.012) (Figure 4).
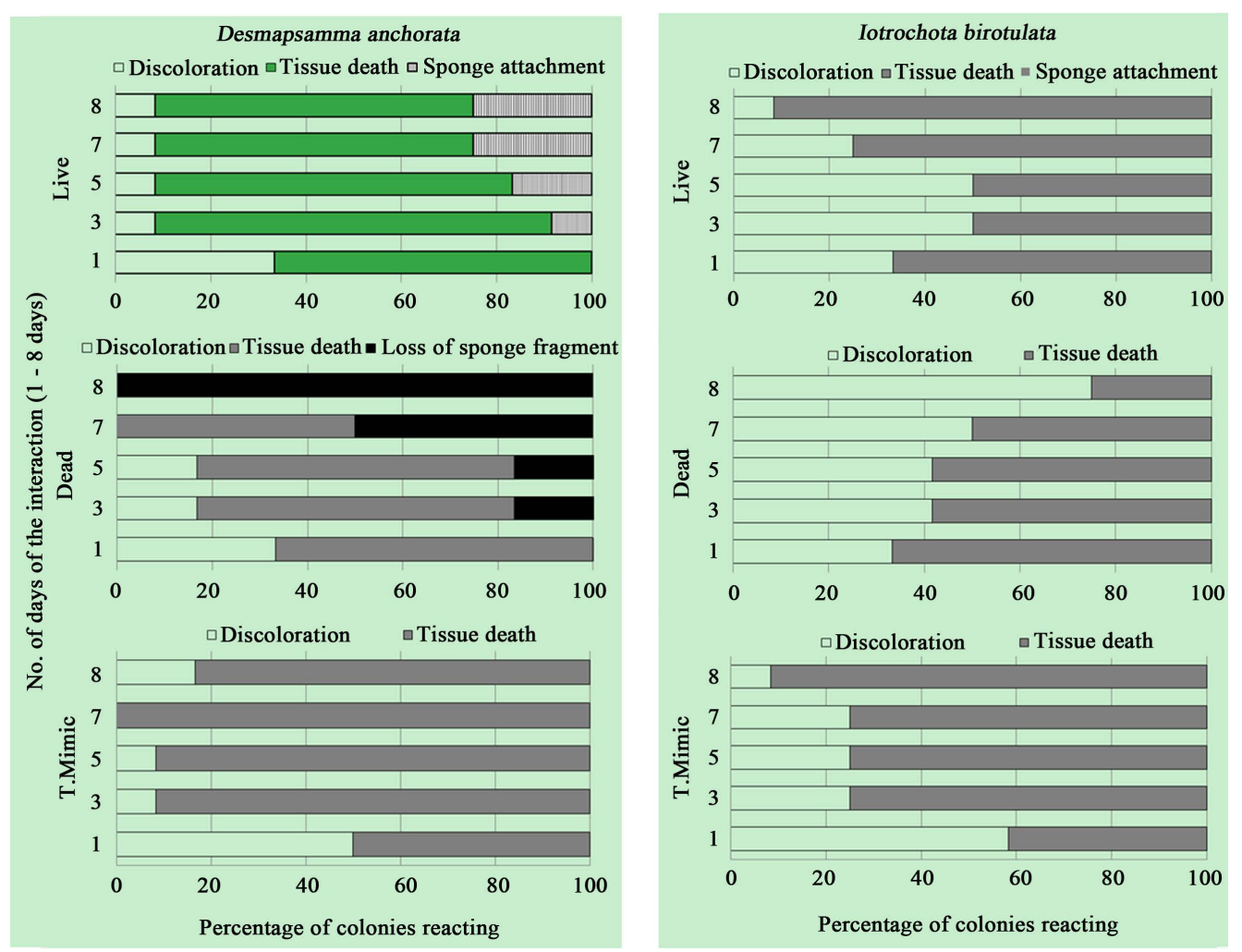

Figure 4. Treatment of sponge-octocoral response effects on the branching octocoral Antillogorgia americana reacting to live dead Desmapsamma anchorata and Iotrochota birotulata as well as the tissue mimic (T. mimic). Responses observed are discoloration, tissue death and attachment presented in percentages for twelve replicates over and eight day period. Note that the attachment response occurs for live sponge fragments of $D$. anchorata within 8 days of the experiment, I. birotulata, takes longer. Significance differences are seen across live-dead and live-T. mimic samples, and no-significance is seen across dead-T. mimic samples. 
On the attachment response, Desmapsamma anchorata and Iotrochota birotulata differed for both the live and the dead fragments $\left(\mathrm{t}_{136}=-2.15, \mathrm{SE}=0.85, \mathrm{P}>0.0329\right)$. The range in responses was different for the live versus inert sponge fragment properties: the responses to live tissue differed from tissue mimics $\left(\mathrm{t}_{136}=2.96\right.$, $\mathrm{SE}$ $=0.83, \mathrm{P}=0.0036$ ), and there were no-significant differences between the tissue mimics and dead sponge fragments $\left(\mathrm{t}_{136}=0.82, \mathrm{SE}=0.78, \mathrm{P}=0.415\right)$ (Figure 4$)$.

The attachment response of the live sponge fragments varied with time of exposure and the interacting species. After eight days, $25 \%$ of $D$. anchorata fragments were attached to A. americana. In contrast, $92 \%$ of the I. birotulata fragments in contact with the same octocoral species caused tissue death but did not become attached. Tissue death occurred faster when the tissue mimic was applied than in the cases of live-sample pairings; we also noted that more than $50 \%$ of the dead fragments were lost before the end of the experiment (Figure 4).

\subsection{Octocoral Overgrowth-Deterrence Explained by Species-Specific Pairings}

By species-specific effects overgrowth-deterrence is meant that the attributes of a given species, either the octocoral or the sponge involved act so as to deter the sponge attachment on the octocoral substrate. When different live sponge-octocoral species pairings were tested, the results mirrored the natural (non-experimental) situation where common epizoic species attached more often than rarely epizoic species $\left(\mathrm{F}_{2,182}=8.16, \mathrm{P}<0.0001\right)$. The response was significantly influenced by the interaction effect of sponge species and the octocoral species tested $\left(F_{2,182}=6.9, P=0.0002\right)$, and the time of exposure for the paired organisms $\left(F_{1,182}=79.88, P<0.0001\right)$.

For the two sponge attributes tested, we found that sponge-octocoral interaction within one category (common or rare epizoic) had similar responses, such as the effects of Desmapsamma anchorata and Iotrochota birotulata on the octocoral Antillogorgia americana $\left(\mathrm{t}_{182}=-0.26, \mathrm{P}=0.0766\right)$, however the response effects across different categories differed (Figure 5). Comparing the effects of attachment and non-attachment of commonly epizoic $D$. anchorata and $I$. birotulata on the ocotocoral A. americana, compared to rarely epizoic Niphates erecta and Ptilocaulis walpersi on the same octocoral were significantly different $\left(t_{182}=2.53, P=0.0123\right.$ and $t_{182}=$ 2.85, $\mathrm{P}=0.0049$ ). Although discoloration and tissue death effects are present in both categories (Figure 5 and Figure 6), the ultimate response of attachment, leading to sponge overgrowth, was completely absent in the spongeoctocoral pairings that do not naturally occur (Figure 6).
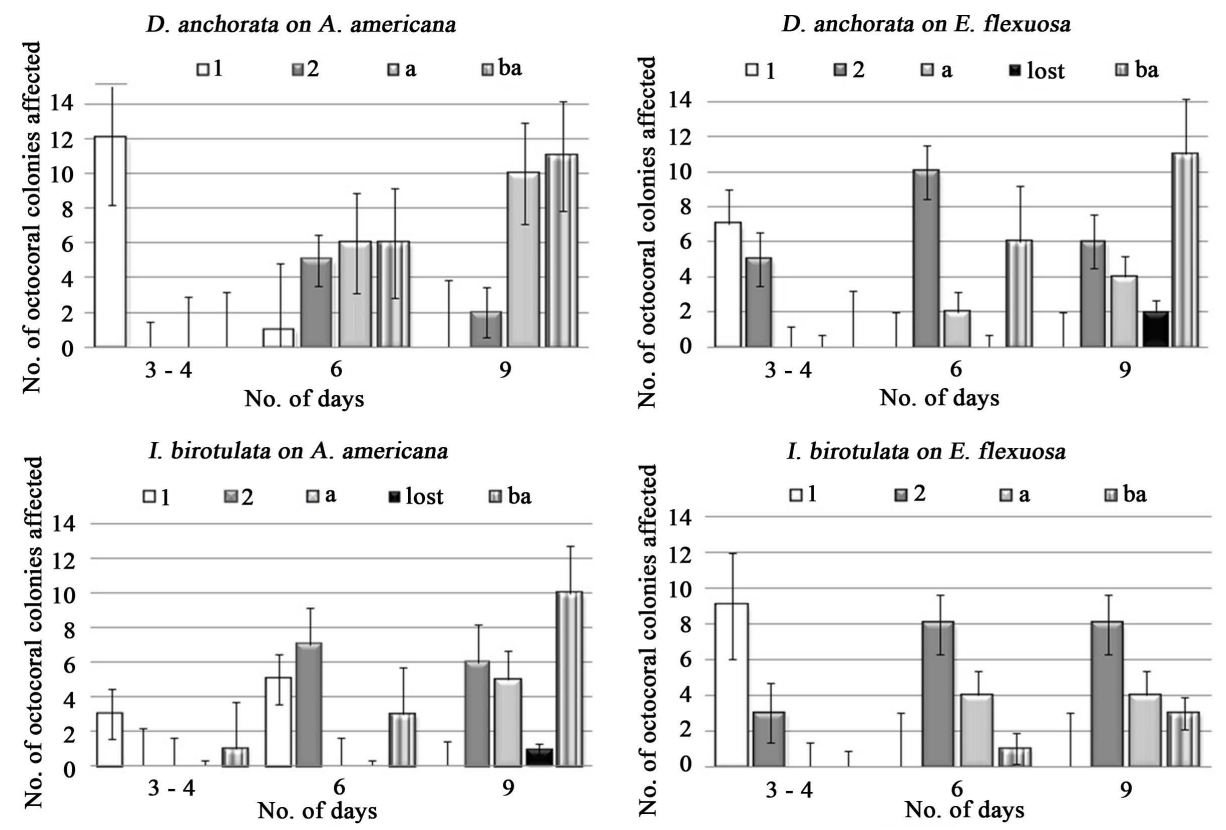

Figure 5. Response on the octocoral substrateas a result of their interaction with Desmapsamma anchorata and Iotrochota birotulata. The distribution of cases in the 4 response categories is shown for each of 3 time points in the experiment. D. anchorata and I. birotulata are common epizoic on octocorals. Responses: 1 , discoloration; 2, tissue death; a, attachment of sponge to live octocoral tissue; ba, attachment of sponge to bare substrate. Note some sponge fragments were lost by the ninth day. 


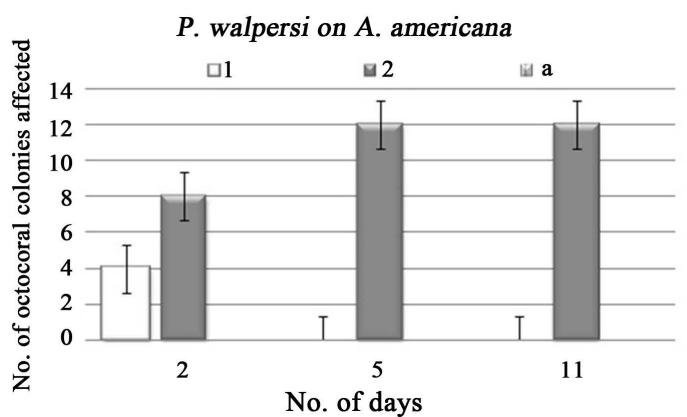

N. erecta on A. americana

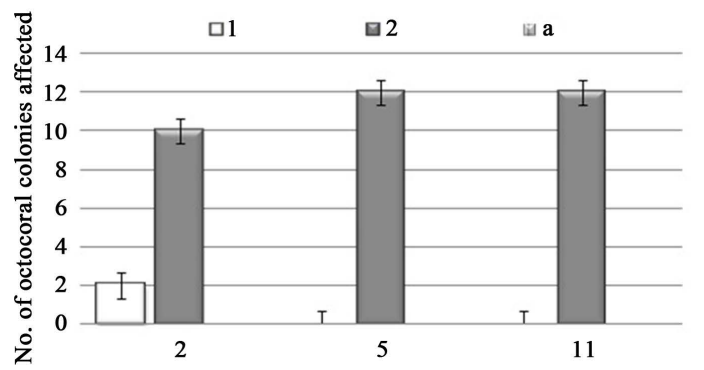

No. of days

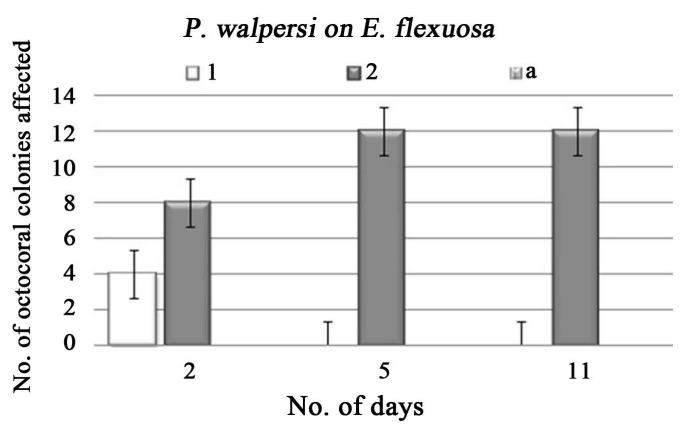

$N$. erecta on E. flexuosa

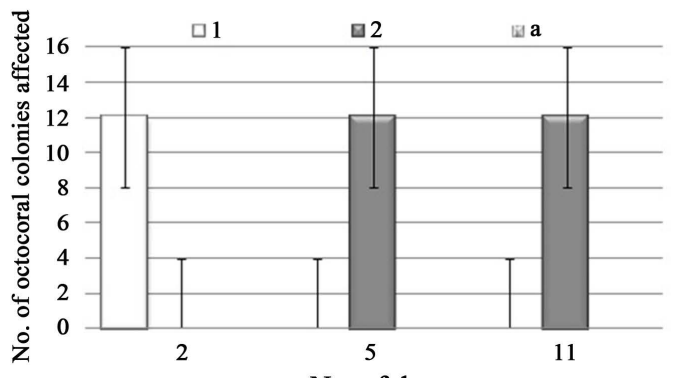

No. of days

Figure 6. Non-overgrowing sponges tested on octocorals that are overgrown. Responses observed on Antillogorgia americana and Eunicea flexuosa when in contact with sponges Ptilocaulis walpersi and Niphates erecta. Response categories in function of time; responses: 1, discoloration; 2, tissue death; a, attachment of sponge to live octocoral substrate. No attachment took place.

\subsection{Octocoral Reaction-Differences in Octocoral Susceptibility to Overgrowth}

In contrast to the previous experiment, where the species pairings were tested for species-specific effects on live substrate only, this experiment measures the ability of a sponge to attach on varying octocoral substrate, testing for increased susceptibility to sponge colonization in the absence of live-tissue on the octocorals more. The response observed on live octocoral tissue, characterized by discoloration and death of the tissue and followed by attachment was influenced by the interaction between sponge and octocoral $\left(\mathrm{F}_{1,211}=23.4, \mathrm{P}<0.0001\right)$ and the number of days of the interaction $\left(\mathrm{F}_{1,211}=51.76, \mathrm{P}<0.0001\right)$. In the case of sponge-octocoral associations between species that are not commonly epizoic, the attachment success was significantly different for live tissue versus bare octocoral axis $\left(\mathrm{t}_{211}=4.84, \mathrm{SE}=0.53, \mathrm{P}<0.0001\right)$. The response was different for Desmapsamma anchorata tested on live Plexaurella nutans where attachment was not observed; however, the attachment response was greater on to the bare axis of $P$. nutans (Figure 7), than in the $D$. anchorata and Antillogorgia americana species pairing (Figure 5), indicating that the bare axis of $P$. nutans can be more susceptible to overgrowth than the bare axis of $A$. americana. Within 3 days of the start of the experiment, $D$. anchorata attached to A. americana, completing a full circle around the octocoral axis (Figure 2(C)). This result was different from the initial tests, were even after eight days of the experiment there was no attachment or overgrowth of $D$. anchorata on the live P. nutans, although signs of discoloration occurred (Figure 7). Results on the octocoral reaction comparing Desmapsamma anchorata and Iotrochota birotulata on the live and bare tissue of Antillogorgia americana and Eunicea flexuosa indicate that attachment success is higher and faster on A. americana than on E. flexuosa, and that the $D$. anchorata is more successful attaching on the bare substrate, than on the live tissue (Figure 5).

\subsection{Growth of Sponges on Octocorals}

Preliminary measurements on growth indicate that different octocoral species, in the sponge-octocoral pairings monitored, appeared to influence the growth of the sponge for Iotrochota birotulata, but not for Desmapsamma anchorata. The mean growth of $I$. birotulata was different on Antillogorgia americana $(M=1.57, \mathrm{SE}=0.68)$, when compared to its growth on Eunicea flexuosa $(M=0.68$, $\mathrm{SE}=1.05), \mathrm{t}_{24}=2.55, \mathrm{P}<0.05$ (Figure 8). How- 
D. anchorata on $P$. nutans

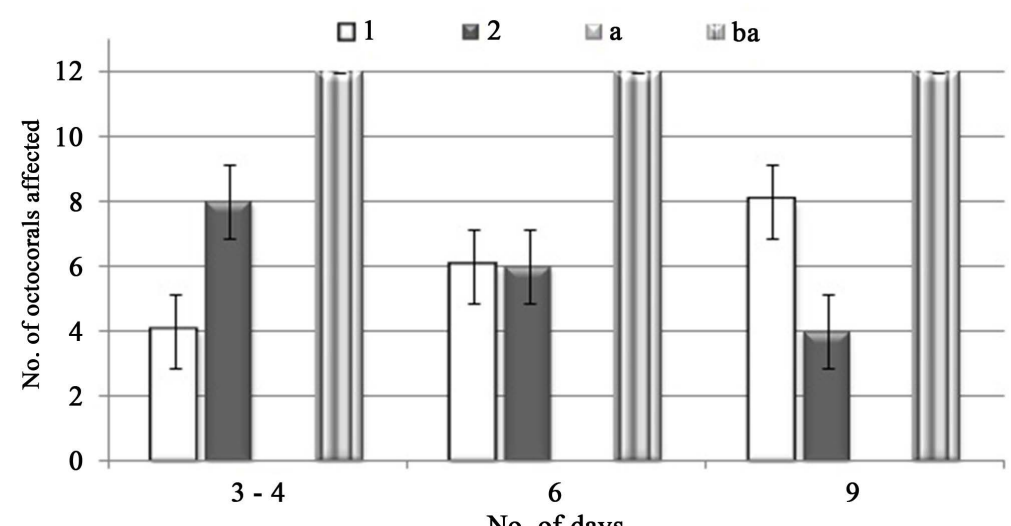

No. of days

Figure 7. Response effects of the octocoral Plexaurella nutans tissue in contact with the sponge Desmapsamma anchorata as a function of time. Responses are: 1 discoloration; 2, tissue death; a, attachment of sponge to live octocoral tissue; ba, attachment of sponge to bare substrate. The distribution of cases in the 4 response categories is shown for each of 3 time points in the experiment. Attachment of $D$. anchorata on the live tissue, a, does not occur, however, attachment on the bare axis; ba, of $P$. nutans is faster than what is seen for the other occurring species interaction previously mentioned.
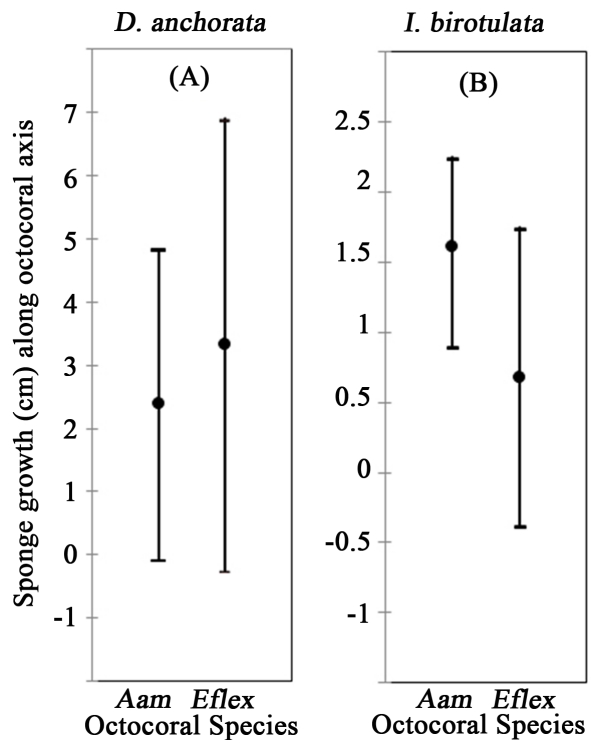

Figure 8. Growth of the sponges Desmapsamma anchorata (A) and Iotrochota birotulata (B) along the octocoral branch axis of Antillogorgia americana and Eunicea flexuosa.

ever, for the faster growing $D$. anchorata on $A$. americana, there was no significant difference $(M=2.32$, $\mathrm{SE}=$ 2.44), compared to E. flexuosa ( $M=3.31$, $\mathrm{SE}=3.59), \mathrm{t}_{25}=0.85, \mathrm{P}>0.05$ (Figure 8).

Differential growth rates measured for the two sponge species resulted in contrasting overgrowth differences. After six months, initial fragments of $D$. anchorata measuring an average initial area of $7 \mathrm{~cm}^{2}$ grew from 7.8 $\mathrm{cm}^{2}$ to $83 \mathrm{~cm}^{2}$; and fragments of $I$. birotulata measuring an average initial area of $9 \mathrm{~cm}^{2}$ grew more moderately, from $10 \mathrm{~cm}^{2}$ to $23 \mathrm{~cm}^{2}$, varying from their initial length along the axis from $5 \mathrm{~cm}$ to $3-14 \mathrm{~cm}$ (Figure 8).

\section{Discussion}

The purpose of this study was to determine the factors that influence sponge attachment and overgrowth on octocorals. Species abundance and their composition on the reefs are influenced by many associations present in 
these habitats [1] [6] [27] [61] [62]. The interactions between sponges and octocorals are important because of their competitive nature, and the sponge's ability to negatively affect and sometimes overgrow octocorals [16] [40].

Using a multinomial response analysis, we determined that there are differences in the response with the varying factors considered. The initial substrate effect of a sponge in contact with an octocoral can be primarily physical, given than an inert sponge mimic can cause as much damage to the octocoral as a live sponge fragment. Also, species-specific interaction influences the outcome of the interaction, as well as the actual state of the substrate at the start of the interaction. Time of exposure is the key to the sponge's attachment and overgrowth. Following a successful attachment to an octocoral, the growth of and overgrowth by the sponge is also influenced by similar factors and sponge species differential growth rate.

\subsection{Physical Effects on Octocorals}

The physical response observed on the octocoral tissue in the sponge-octocoral interactions varied across the different properties of the sponges that were in direct contact with its surface. In general, the effect of discoloration that leads to tissue death is observed across most interactions, with attachment only possible for live sponge fragments of species that naturally overgrow the octocoral. Considering that the sequential response is similar across all interacting sponge type tested helps understand how a neighboring organisms, being inert or alive, can negatively affect the integrity of the octocoral and when attachment occurs both their living tissue and the supporting axis becomes a substrate. In our experiment, although the number of days differed slightly (Figure 4), the sponge mimic had as great an effect in causing tissue death as the living sponge tissue, when in contact to the octocoral, indicating that, in part, the effect was primarily physical. In situ, 50\% of the dead sponges were lost before the end of the experiment; dead sponge fragments of Desmapsamma anchorata tissue tended to disintegrate and fragments of Iotrochota birotulata probably fell because these fragments were more rigid and could not resist the drag from the water column; the commercial sponge skeleton was of a soft, elastic consistency and remained in the pairing longer, tending to disintegrate eventually while still negatively affecting the octocoral substrate (Figure 4).

The physical effects of direct contact can cause abrasion and damage on the octocorals base, effects that are conducive to high octocoral mortality [10] [63]. In general, sponges benefit from these interactions by gaining structural support and protection from predators [16] [62] [64], while octocoral axes can become debilitated [5] [10] and susceptible to other foulers. Similarly, this effect has also been observed on scleractinian corals, their susceptibility to being overgrown increases when their polyp-covered surface is affected by smothering action [65].

\subsection{Octocoral Overgrowth-Deterrence Explained by Species-Specific Pairings}

The ability of a sponge to attach to an octocoral is influenced by species-specific effects, this influencing the frequency of sponge-octocoral interactions observed on a reef. The factors considered in our experiments, sponge species, octocoral species, common versus rare epizoics, as well as the number of days of the interaction, determined the observed outcome. Of particular interest in this part of the study was the response effect of spongeoctocoral species pairings that are rarely epizoic or overgrown on a reef, such as test trials of Eunicea mammosa (Lamouroux) in contact with Iotrochota birotulata, where the octocoral tissue elicits a response that resembles an inflammation on the area of contact. A different reaction was observed on the rarely overgrown Plexaurella nutans when in contact with Desmapsamma anchorata; here the octocoral tissue changes color, from yellow to black (Figure 2(B)). In both of these cases there was no sign of sponge attachment, even after 10 days of interaction (Figure 6 and Figure 7).

\subsection{Octocoral Reaction-Differences in Octocoral Susceptibility to Overgrowth}

Common epizoic sponges like Desmapsamma anchorata and Iotrochota birotulata are rarely found to overgrow certain branching octocorals. The question on how the octocorals' susceptibility to overgrowth varies in function of loss of the integrity of its substrate was tested. Different from the octocorals deterrence observed when the sponge was in direct contact to live octocoral tissue, we observed that the response changed resulting in sponge overgrowth when the scleroproteinaceus axis of Plexaurella nutans had been compromised (Figure 7). For 
sponge species that overgrow, attachment of a fragment is always faster when in contact with bare octocoral axis rather than the polyp-covered surface. Therefore, an increase in the susceptibility of the octocoral substrate allows for an epizoic sponge, like D. anchorata, to attach and grow not only on octocoral species on which it naturally occurs, but also on others, although the process is slower.

In a dynamic reef context, sponge-octocoral interactions leading to attachment and overgrowth are facilitated by a compromised host; smothered or dead octocoral tissue being more susceptible to overgrowth than a healthy one, and then by wave action or a limited time of interaction. Sponges growing on octocorals are known to have an effect on their hosts [62] that is likened to an immunological response [2] [16] [66] that varies from species to species. Visually, this response is obvious by the exudates of slime, common for both tested branching octocorals, Antillogorgia americana and Eunicea flexuosa, when exposed to the sponges Desmapsamma anchorata or Iotrochota birotulata. One exception is the nature of the response seen in Carijoa riisei (Duchassaing \& Michelotti) when overgrown by $D$. anchorata; here their interaction leads to formation of a continuous collagen sheet on the octocoral surface, with no exudate [2] [16].

\subsection{Growth Measurements of Sponges Attached to Octocorals}

The recorded sponge growth from our experiments simulates natural conditions where sponges growing over octocorals on the reef are exposed to breakage and predation [20] [56] [67]. As a result, their growth rate can be negative or positive. Growth of sponges is species-specific [19] and affected by the nature of the substrate over which they grow. Comparing growth of one sponge species tested on 2 different octocoral substrates: Differences in mean growth were observed in Iotrochota birotulata when growing on Antillogorgia americana versus on Eunicea flexuosa, but not in Desmapsamma anchorata, which can grow four times faster than I. birotulata; differences in its growth rate on the two tested octocoral substrates were not significant. Desmapsamma anchorata's attribute of spurred growth also means that it is frail and breakable, increased wave action can break it off its overgrowing substrate [3] [60], in contrast to Iotrochota birotulata that grows slower but is more persistent.

\subsection{Other Factors That Affect Sponge Overgrowth}

Next to interacting species influencing sponge growth, environmental aspects such as the position of the animal in the water column [8] [57] the speed of water flow [58], food content, resource allocation [68] [69], as well as associated fauna or symbionts [62] [70] [71] are important in this process; furthermore sponge growth is also influenced by the ecological effects of predation [56].

Differences across other taxa that interact with sponges are also noted, not all of them negative. For instance in sponge-coral associations, sponges have been observed to enhance the survival of the corals [38] or to prevent other organisms from fouling them [72]. However, in the case of corals, overgrowth susceptibility increases when the coral surface is affected by smothering [65].

In sponge-octocoral interactions, sponges tend to impact branching octocorals negatively by their growth; this effect is best described as 'structural parasitism' or lianas [73] where sponges topple the octocorals over which they grow [8]. Going back to Stebbing's definition of overgrowth, it is important to take note of organisms that extend their edge over others, as once this step is taken, the aggressive organism has the potential to overgrow the other [36] for instance, a sponge like Desmapsamma anchorata, known to have substantial growth rates, can double its length along an octocoral axis in only 6 months.

\section{Conclusions}

Octocorals are unique in enhancing habitat complexity of reefs and providing natural corridors for fishes. Understanding the factors and the chronological stages that lead to attachment and overgrowth by space competitors is important for any reef ecologist or resource manager interested in preserving the natural balance of such associations.

In the context of community successions and the successful sponge attachment and overgrowth, we recommend that further studies determine the ability of octocorals to recover after the removal of a sponge. Under natural circumstances a sponge fragment can be dislodged from the octocoral through wave action [3] [43] [60] or by the grazing action of spongivorous fishes which are known for playing a role in structuring reef-sponge communities [74] [75]. In our preliminary observations in Belize, when sponge overgrowth was removed from 
octocoral colonies and their axes cleaned and scrubbed, removing all trace of sponge tissue, some octocorals had restored their tissue after six months, others were covered with cyanobacteria. For those that restored their tissue, a defined line or scar could still be observed in the area where the new tissue had regenerated. An octocorals ability to restore its tissue is important for its survival, as noted above, because once exposed, the axis is susceptible fouling and weakening its structural integrity [6] [59] [63] [76] and, hence, impacts the animals' abundances [10]. Further studies are needed to determine the conditions that influence octocoral tissue regeneration after an overgrowing sponge has been removed.

\section{Acknowledgements}

For support and assistance in the field, we thank N. Manrique and A. Chaves-Fonnegra. Warm thanks go to the staff and new friends at Carrie Bow Cay, and to the anonymous reviewers who improved the manuscript. E. Mclean also thanks M. A. Coffroth, K. Dittmar de la Cruz and C. E. Mitchell for their guidance during the planning phase of this research; and Howard R. Lasker for his support and comments that improved the manuscript. This study was done with the sponsorship of a Smithsonian Institution Minority Fellowship and the support of the Caribbean Coral Reef Ecosystems (CCRE) program (2009-2010); CCRE Contribution number 964.

\section{References}

[1] Wulff, J.L. (1997) Mutualisms among Species of Coral Reef Sponges. Ecology, 78, 146-159.

[2] Calcinai, B.P., Bavestrello, G. and Cerrano, C.O. (2004) Dispersal and Association of Two Alien Species in the Indonesian Coral Reefs: The Octocoral Carijoa riisei and the Demosponge Desmapsamma anchorata. Journal of the Marine Biological Association, 84, 937-941. http://dx.doi.org/10.1017/S0025315404010227h

[3] Mclean, E.L. (2006) Ecology of the Encrusting Sponge Desmapsamma anchorata. M.S. Thesis, University of Puerto Rico, Mayaguez.

[4] Mclean, E.L. and Yoshioka, P.M. (2008) Substratum Effects on the Growth and Survivorship of the Sponge Desmapsamma anchorata. Caribbean Journal of Science, 44, 83-89. http://caribjsci.org/Mar08/44_83-89.pdf

[5] Mclean, E.L. and Yoshioka, P.M. (2007) Associations and Interactions between Gorgonians and Sponges. In: Custódio, M.R., Lôbo-Hajdu, G., Hajdu, E. and Muricy, G., Eds., Porifera Research—Biodiversity Innovation \& Sustainability, Museu Nacional de Rio de Janeiro, Brasil, 443-448.

[6] Wahle, C. (1980) Detection, Pursuit, and Overgrowth of Tropical Gorgonians by Milleporid Hydrocorals: Perseus and Medusa Revisited. Science, 209, 689-691. http://dx.doi.org/10.1126/science.209.4457.689

[7] Tunnell, J. and Nelson, T. (1989) A High Density-Low Diversity Octocoral Community in the Southwestern Gulf of Mexico. American Academy of Underwater Sciences, Woods Hole, 325-282. http://dspace.rubicon-foundation.org:8080/xmlui/handle/123456789/10251

[8] Mclean, E.L. and Lasker, H.R. (2013) Height Matters: Position above the Substratum Influences the Growth of Two Demosponge Species. Marine Ecology, 34, 122-129. http://dx.doi.org/10.1111/j.1439-0485.2012.00523.x

[9] Yoshioka, P.M. and Yoshioka, B.B. (1989) A Multispecies, Multiscale Analysis of Spatial Pattern and Its Application to a Shallow-Water Gorgonian Community. Marine Ecology Progress Series, 59, 257-264. http://dx.doi.org/10.3354/meps054257

[10] Yoshioka, P.M. and Yoshioka, B.B. (1991) A Comparison of the Survivorship and Growth of Shallow-Water Gorgonian Species of Puerto Rico. Marine Ecology Progress Series, 69, 253-260. http://dx.doi.org/10.3354/meps069253

[11] Leong, W. and Pawlik, J. (2010) Evidence of a Resource Trade-Off between Growth and Chemical Defenses among Caribbean Coral Reef Sponges. Marine Ecology Progress Series, 406, 71-78. http://dx.doi.org/10.3354/meps08541

[12] Rützler, K. (1970) Spatial Competition among Porifera: Solution by Epizoism. Oecologia, 5, 85-95. http://dx.doi.org/10.1007/BF00347624

[13] Connell, J.H. (1961) The Influence of Interspecific Competition and Other Factors on the Distribution of the Barnacle Chthamalus Stellatus. Ecology, 42, 710-723. http://dx.doi.org/10.2307/1933500

[14] Wilkinson, C.R. and Cheshire, A.C. (1989) Patterns in the Distribution of Sponge Populations across the Central Great Barrier Reef. Coral Reefs, 8, 127-134. http://dx.doi.org/10.1007/BF00338268

[15] Ling, S. (2008) Range Expansion of a Habitat-Modifying Species Leads to Loss of Taxonomic Diversity: A New and Impoverished Reef State. Oecologia, 156, 883-894. http://dx.doi.org/10.1007/s00442-008-1043-9

[16] van Soest, R.W.M. and Verseveldt, J. (1987) Unique Symbiotic Octocoral-Sponge Association from Komodo. In- 
do-Malayan Zoology, 41, 27-32.

[17] Bergquist, P.R. (1978) Sponges. Hutchinson, London, 268 p.

[18] Wulff, J.L. (1999) A Sponge That Cheats on Diffuse Mutualism among Other Sponge Species. Memoirs-Queensland Museum, 44, 686-686.

[19] Wulff, J.L. (2006) Resistance vs. Recovery: Morphological Strategies of Coral Reef Sponges. Functional Ecology, 20, 699-708. http://dx.doi.org/10.1111/j.1365-2435.2006.01143.x

[20] Jackson, J.B. and Buss, L. (1975) Alleopathy and Spatial Competition among Coral Reef Invertebrates. Proceedings of the National Academy of Sciences of the United States of America, 72, 5160-5163. http://dx.doi.org/10.1073/pnas.72.12.5160

[21] Vicente, V. (1978) An Ecological Evaluation of the West Indian Demosponge Anthosigmella varians (Hadromerida: Spirastrellidae). Bulletin of Marine Science, 28, 771-779.

[22] Russ, G.R. (1982) Overgrowth in a Marine Epifaunal Community: Competitive Hierarchies and Competitive Networks. Oecologia, 53, 12-19. http://dx.doi.org/10.1007/BF00377130

[23] Suchanek, T. and Carpenter, R. (1983) Sponges as Important Space Competitors in Deep Caribbean Coral Reef Communities. In: Contributions \#109 of the West Indies Laboratory (St. Croix, USVI) Symposium Series, 55-60.

[24] Aerts, L.A.M. and van Soest, R.W.M. (1997) Quantification of Sponge/Coral Interactions in a Physically Stressed Reef Community, NE Colombia. Marine Ecology Progress Series, 148, 125-134. http://dx.doi.org/10.3354/meps148125

[25] Diaz, M.M.C., Rützler, K. and Rutzler, K. (2001) Sponges: An Essential Component of Caribbean Coral Reefs. Bulletin of Marine Science, 69, 535-546.

[26] Bell, J.J. and Barnes, D.K.A. (2003) The Importance of Competitor Identity, Morphology and Ranking Methodology to Outcomes in Interference Competition between Sponges. Marine Biology, 143, 415-426. http://dx.doi.org/10.1007/s00227-003-1081-0

[27] Rützler, K. (2004) Sponges on Coral Reefs, a Community Shaped by Competitive Cooperation. Bulletin of Museum of 1st Biology University, Genova, 68, 85-148.

[28] Whittaker, R. and Feeny, P. (1971) Allelochemics: Chemical Interactions between Species. Science, 171, 757-770. http://dx.doi.org/10.1126/science.171.3973.757

[29] Sammarco, P.W., Coll, J.C., Barre, S. and Willis, B. (1983) Competitive Strategies of Soft Corals (Coelenterata: Octocorallia): Allelopathic Effects on Selected Scleractinian Corals. Coral Reefs, 1, 173-178. http://dx.doi.org/10.1007/BF00571194

[30] Porter, J.W. and Targett, N.M. (1988) Allelochemical Interactions between Sponges and Corals. Biological Bulletin, 175, 230. http://dx.doi.org/10.2307/1541563

[31] Thacker, R.W., Becerro, M.A., Lumbang, W.A. and Paul, V.J. (1998) Allelopathic Interactions between Sponges on a Tropical Reef. Ecology, 79, 1740-1750. http://dx.doi.org/10.2307/176792

[32] Engel, S. and Pawlik, J. (2000) Allelopathic Activities of Sponge Extracts. Marine Ecology Progress Series, 207, 273281. http://dx.doi.org/10.3354/meps207273

[33] Bryan, P. (1973) Growth Rate, Toxicity, and Distribution of the Encrusting Sponge Terpios sp. (Hadromerida: Suberitidae) in Guam, Mariana Islands. Micronesica, 9, 237-242.

[34] Aerts, L. (1998) Sponge/Coral Interactions in Caribbean Reefs: Analysis of Overgrowth Patters in Relation to Species Identity and Cover. Marine Ecology Progress Series, 175, 251-259. http://dx.doi.org/10.3354/meps175241

[35] Chaves-Fonnegra, A., Castellanos, L., Zea, S., Duque, C., Rodríguez, J. and Jiménez, C. (2008) Clionapyrrolidine AA Metabolite from the Encrusting and Excavating Sponge Cliona tenuis That Kills Coral Tissue upon Contact. Journal of Chemical Ecology, 34, 1565-1574. http://dx.doi.org/10.1007/s10886-008-9565-5

[36] Stebbing, A.R.D. (1973) Competition for Space between the Epiphytes of Fucus serratus L. Journal of the Marine Biological Association of the United Kingdom, 53, 247. http://dx.doi.org/10.1017/S0025315400022244

[37] Harris, J.A. (1978) The Ecology of Marine Epifaunal Communities on the Pilling of Portsea Pier. BSc (Hons) Thesis, Department of Zoology, University of Melbourne, Melbourne.

[38] Wulff, J.L. and Buss, L.W. (1979) Do Sponges Help Hold Coral Reefs Together? Nature, 281, 474-475. http://dx.doi.org/10.1038/281474a0

[39] Green, G., Fuentes, L. and Gómez, P. (1988) Nuevos registros de porífera del arrecife La Blanquilla, Veracruz, México. http://repositorio.fciencias.unam.mx:8080/xmlui/handle/11154/62025

[40] Zea, S. (1987) Esponjas del Caribe Colombiano, Dictyoceratida, Dendroceratida, Verongida, Haplosclerida, Poecilosclerida, Halichondrida, Axinellida, Desmophorida y Homosclerophorida. Editorial Catálogo Cientifico, Bogotá, 286.

[41] Uriz, M., Turon, X., Becerro, M. and Galera, J. (1996) Feeding Deterrence in Sponges. The Role of Toxicity, Physical 
Defenses, Energetic Contents, and Life-History Stage. Journal of Experimental Marine Biology and Ecology, 205, 187-204. http://dx.doi.org/10.1016/S0022-0981(96)02609-3

[42] Kubanek, J., Whalen, K., Engel, S., Kelly, S., Henkel, T., Fenical, W. and Pawlik, J. (2002). Multiple Defensive Roles for Triterpene Glycosides from Two Caribbean Sponges. Oecologia, 131, 125-136. http://dx.doi.org/10.1007/s00442-001-0853-9

[43] Wulff, J.L. (2009) Sponge Community Dynamics on Caribbean Mangrove Roots: Significance of Species Idiosyncrasies. In: Rutzler, K., Lang, M.A. and Macintyre, I.G., Eds., Smithsonian Contributions to the Marine Sciences, Smithsonian Institution, Washington DC, 501-514.

[44] Rützler, K., Diaz, M.C., van Soest, R.W.M., Zea, S., Smith, K.P., Alvarez, B. and Wulff, J.L. (2000) Diversity of Sponge Fauna in Mangrove Ponds, Pelican Cays, Belize. Atoll Research Bulletin, 467, 229-248. http://dx.doi.org/10.5479/si.00775630.467.229

[45] Collin, R., Diaz, M.C., Norenburg, J. and Rocha, R.M. (2005) Photographic Identification Guide to Some Common Marine Invertebrates of Bocas Del Toro, Panama. Caribbean, 41, 638-707. http://caribjsci.org/dec05 Special issue/41_638-707.pdf

[46] Crocker, L.A. and Reiswig, H.M. (1981) Host Specificity in Sponge-Encrusting Zoanthidea (Anthozoa: Zoantharia) of Barbados, West Indies. Marine Biology, 65, 231-236. http://dx.doi.org/10.1007/BF00397116

[47] Lewis, S., Rützler, K. and Macintyre, I. (1982) Sponge-Zoanthid Associations: Functional Interactions. Smithsonian Contributions to the Marine Science, 12, 465-474.

[48] Hooper, J. and Van Soest, R. (2002) Systema Porifera. A Guide to the Classification of Sponges. Springer, New York. http://dx.doi.org/10.1007/978-1-4615-0747-5_1

[49] Engel, S. and Pawlik, J. (2005) Interactions among Florida Sponges. II. Mangrove Habitats. Marine Ecology Progress Series, 303, 145-152. http://dx.doi.org/10.3354/meps303145

[50] van Soest, R.W.M. (1980) Marine Sponges from Curacao and Other Caribbean Localities: Part II: Haplosclerida. Foundation for Scientific Research in Surinam and the Netherlands Antilles, Utrecht, 173.

[51] Rützler, K. (2009) Sponges (Porifera) of the Gulf of Mexico. In: Gulf of Mexico Origin, Waters and Biota, Texas A\&M University Press, College Station, 285-313.

[52] Hill, M. (1998) Spongivory on Caribbean Reefs Releases Corals from Competition with Sponges. Oecologia, 117, 143-150. http://dx.doi.org/10.1007/s004420050642

[53] Macintyre, I., Bayer, F., Logan, M. and Skinner, H. (2000) Possible Vestige of Early Phosphatic Biomineralization in Gorgonian Octocorals (Coelenterata). Geology, 28, 455-458.

[54] Sánchez, J.A. and Wirshing, H.H. (2005) A Field Key to the Identification of Tropical Western Atlantic Zooxanthellate Octocorals (Octocorallia: Cnidaria). Caribbean Journal of Science, 41, 508-522.

[55] Wilkinson, C. and Vacelet, J. (1979) Transplantation of Marine Sponges to Different Conditions of Light and Current. Journal of Experimental Marine Biology and Ecology, 37, 91-104. http://dx.doi.org/10.1016/0022-0981(79)90028-5

[56] Wulff, J. (2006) A Simple Model of Growth Form-Dependent Recovery from Disease in Coral Reef Sponges, and Implications for Monitoring. Coral Reefs, 25, 419-426. http://dx.doi.org/10.1007/s00338-006-0110-0

[57] Duckworth, A.R., Battershill, C.N. and Bergquist, P.R. (1997) Influence of Explant Procedures and Environmental Factors on Culture Success of Three Sponges. Aquaculture, 156, 251-267. http://dx.doi.org/10.1016/S0044-8486(97)00131-2

[58] Duckworth, A.R., Battershill, C.N. and Schiel, D.R. (2004) Effects of Depth and Water Flow on Growth, Survival and Bioactivity of Two Temperate Sponges Cultured in Different Seasons. Aquaculture, 242, 237-250. http://dx.doi.org/10.1016/j.aquaculture.2004.08.046

[59] Feingold, J.S. (1988) Biological Studies of a Cyanobacterial Infection on the Caribbean Sea Plume Pseudopterogorgia acerosa (Coelenterata, Octocorallia). Proceedings of the 6th International Coral Reef Symposium, Townsville, 8-12 August 1988, 157-162.

[60] Wulff, J.L. (2005) Trade-Offs in Resistance to Competitors and Predators, and Their Effects on the Diversity of Tropical Marine Sponges. Journal of Animal Ecology, 74, 313-321. http://dx.doi.org/10.1111/j.1365-2656.2005.00925.x

[61] Buss, L.W. and Jackson, J.B.C. (1979) Competitive Networks : Nontransitive Competitive Relationships in Cryptic Coral Reef Environments. The American Naturalist, 113, 223-234. http://www.jstor.org/stable/2460201 http://dx.doi.org/10.1086/283381

[62] Wulff, J.L. (2006) Ecological Interactions of Marine Sponges. Canadian Journal of Zoology, 84, 146-166. http://dx.doi.org/10.1139/z06-019

[63] Cary, L.R. (1914) Observations upon the Growth Rate and Oecology of Gorgonians. Publishing Carnegie Institute, 
Washington DC, 79-90.

[64] Uriz, M.J., Rosell, D. and Martin, D. (1992) The Sponge Population of the Cabrera Archipelago (Balearic Islands): Characteristics, Distribution, and Abundance of the Most Representative Species. Marine Ecology, 13, 101-117. http://dx.doi.org/10.1111/j.1439-0485.1992.tb00343.x

[65] Goreau, T.F. (1959) The Ecology of Jamaican Coral Reefs I. Species Composition and Zonation. Ecology, 40, 67-90. http://dx.doi.org/10.2307/1929924

[66] Simpson, T. and Langenbruch, P. (1984) Effects of Germanium on the Morphogenesis of a Complex Silica Structure and on the Assembly of the Collagenous Gemmule Coat in a Freshwater Sponge. Biology of the Cell, 50, 181-190. http://dx.doi.org/10.1007/978-1-4684-7636-1_13

[67] Sarà, M. (1970) Competition and Cooperation in Sponge Populations. Symposium of the Zoological Society of London, 25, 273-284.

[68] Sebens, K. (1985) Community Ecology of Vertical Rock Walls in the Gulf of Maine, USA: Small-Scale Processes and Alternative Community States. In: Moore, P.G. and Seed, R., Ed., The Ecology of Rocky Coasts, Columbia University Press, New York, 346-371.

[69] Walters, K.D. and Pawlik, J.R. (2005) Is There a Trade-Off between Wound-Healing and Chemical Defenses among Caribbean Reef Sponges? Integrative and Comparative Biology, 45, 352-358. http://dx.doi.org/10.1093/icb/45.2.352

[70] Rosell, D. and Uriz, M.J. (1992) Do Associated Zooxanthellae and the Nature of the Substratum Affect Survival, Attachment and Growth of Cliona viridis (Porifera: Hadromerida)? An Experimental. Marine Biology, 114, 503-507. http://dx.doi.org/10.1007/BF00350042

[71] Hill, M.S. (1996) Symbiotic Zooxanthellae Enhance Boring and Growth Rates of the Tropical Sponge Anthosigmella varians forma varians. Marine Biology, 125, 649-654. http://dx.doi.org/10.1007/BF00349246

[72] Bell, J.J. and Barnes, D.K.A. (2000) A Sponge Diversity Centre within a Marine “Island.” Hydrobiologia, 440, 55-64. http://dx.doi.org/10.1007/978-94-017-1982-7_6

[73] Stevens, G.C. (1987) Lianas as Structural Parasites: The Bursera simaruba Example. Ecology, 68, 77-81. http://dx.doi.org/10.2307/1938806

[74] Wulff, J.L. (1994) Sponge Feeding by Caribbean Angelfishes, Trunkfishes, and Filefishes. In: van Soests, R.W.M., van Kempen, T.M.G. and Braekman, J.C., Eds., Sponges in Time and Space, Balkema, Rotterdam, 265-271.

[75] Pawlik, J.R. (1998) Coral Reef Sponges: Do Predatory Fishes Affect Their Distribution? Limnology and Oceanography, 43, 1396-1399. http://dx.doi.org/10.4319/lo.1998.43.6.1396

[76] Birkeland, C. (1974) The Effect of Wave Action on the Population Dynamics of Gorgonia ventalina Linnaeus. Studies of Tropical Oceanography, 12, 115-126. 
Scientific Research Publishing (SCIRP) is one of the largest Open Access journal publishers. It is currently publishing more than 200 open access, online, peer-reviewed journals covering a wide range of academic disciplines. SCIRP serves the worldwide academic communities and contributes to the progress and application of science with its publication.

Other selected journals from SCIRP are listed as below. Submit your manuscript to us via either submit@scirp.org or Online Submission Portal.
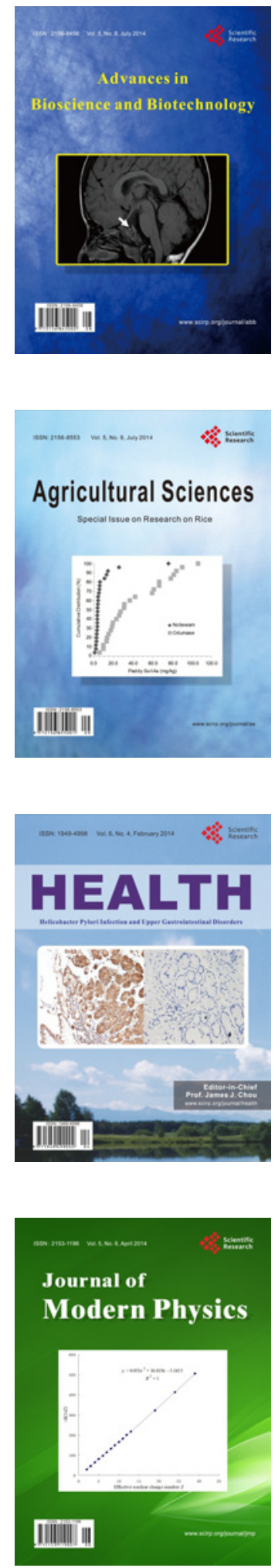
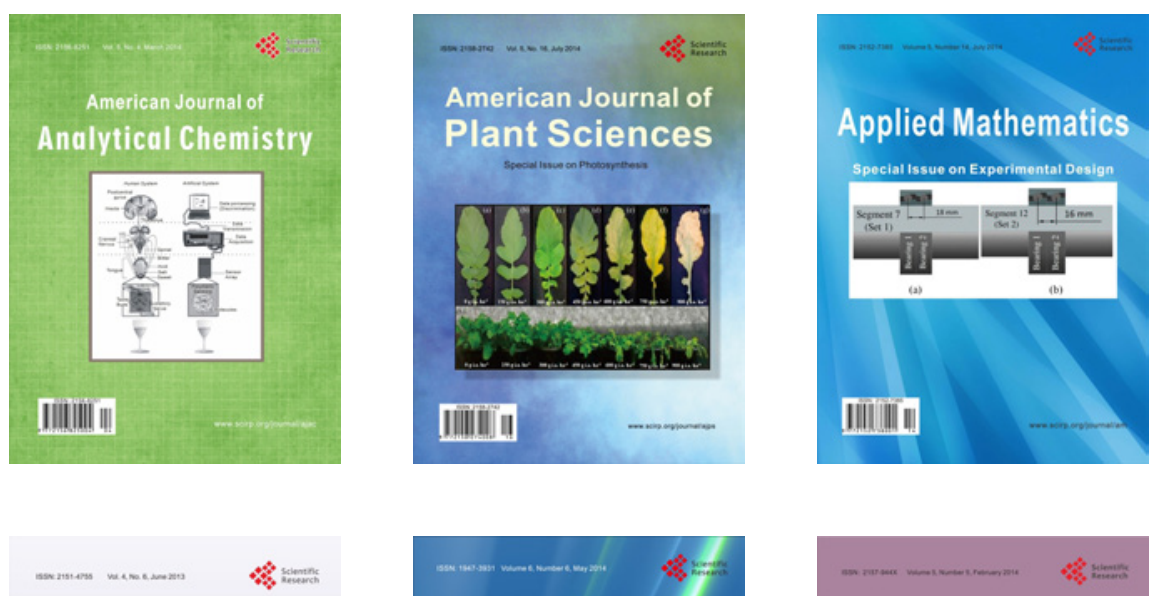

Creative Education
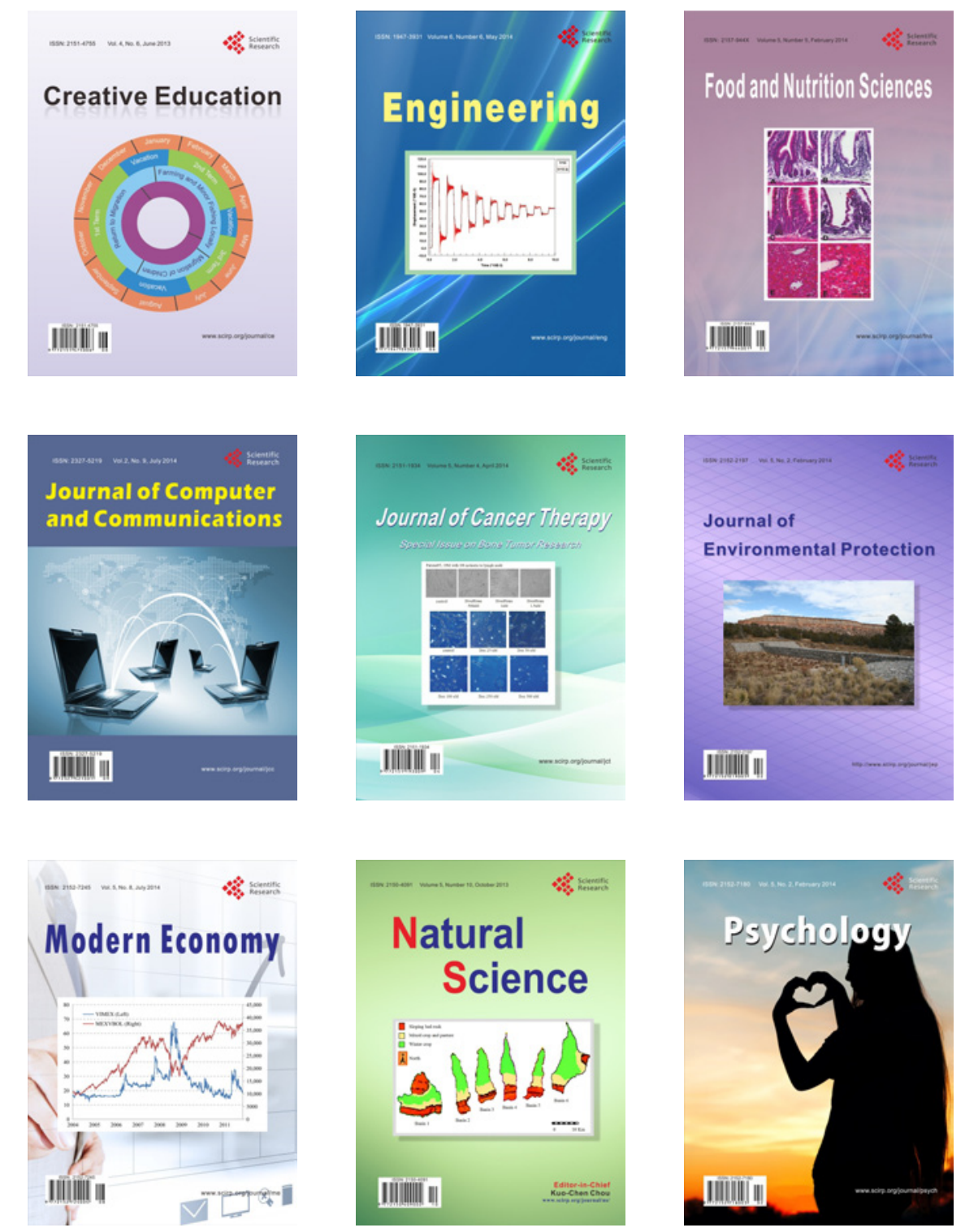